\title{
ХРАНИТЕЛЬ ДИНАСТИИ ПАЛИНОЛОГОВ
}

\section{(C) 2020 г. А. К. Жамангара}

Палеонтолог, палинолог, геолог, геоархеолог Нигматова Саида Араповна отмечает свой юбилей. С. А. Нигматова является продолжателем удивительной семейной династии палинологов. Она внесла весомый вклад в палеоботанику, биостратиграфию и геоархеологию. В статье кратко изложен научный путь С. А. Нигматовой - от аспиранта до известного ученого, возглавляющего единственную уникальную лабораторию палинологии при Институте геологических наук им. К. И. Сатпаева в Казахстане. В статье особо отмечается весомый вклад С. А. Нигматовой в археологию. Заключения, полученные С. А. Нигматовой на основе палинологического анализа, позволили расширить представления о природно-климатических условиях формирования разных культур на территории Казахстана. геоархеология

Ключевые слова: Нигматова Саида Араповна, палинология, палеонтология,

Нигматова Саида Араповна палеонтолог, геолог, геоархеолог родилась 27 апреля 1970 году в городе Алма-Ата. Саида Араповна является продолжателем удивительной семейной династии палинологов: три поколения женщин этой семьи посвятили свою жизнь палинологии - науке, основанной на изучении ископаемых пыльцы и спор растений.

Первой в Казахстане увлеклась изучением палеоботаники и палеопалинологии известный ученый, кандидат биологических наук Рукия Яруловна Абузярова, более 40 лет преподававшая палинологию в КазГУ им. С. М. Кирова. Многие годы Рукия Яруловна изучала палеофлору кайнозоя Казахстана. Она была единственным казахстанским палинологом, принявшим участие в I Международной палинологической конференции в Таксоне (США) в 1962 г. Палинологи со всего мира знали нашу страну по ее работам, присылали ей свои статьи, монографии. По ее стопам пошла и племянница Байбулатова Раиса Биктемировна, мама Саиды Нигматовой. Р. Б. Байбулатова 37 лет проработала в Поисково-съемочной экспедиции

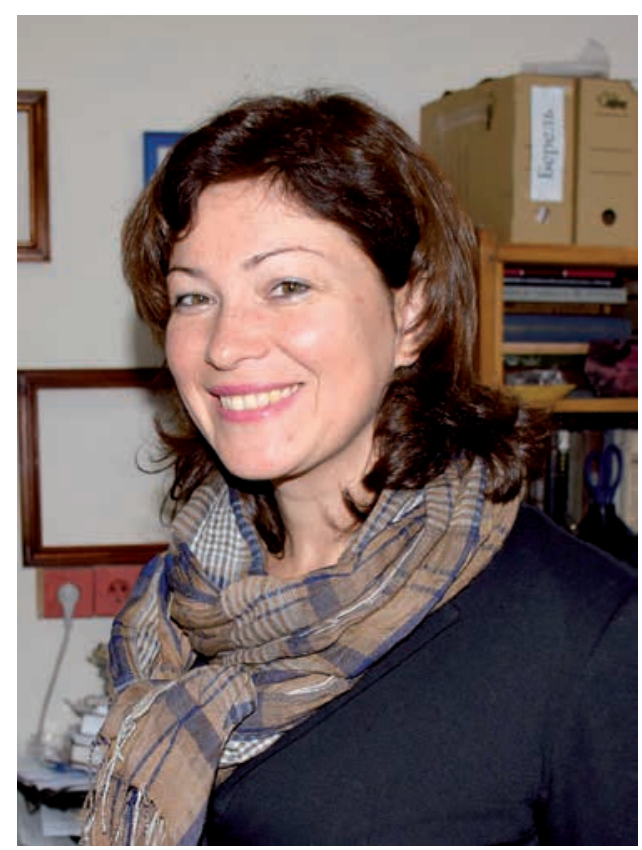

Рис. 1. Саида Араповна Нигматова

Fig. 1. Saida A. Nigmatova 
Южно-Казахстанского Геологического управления. Работы Р. Б. Байбулатовой хорошо известны геологам, изучающим кайнозойские отложения Казахстана. Ею детально изучены и расчленены палеогеновые, неогеновые и четвертичные отложения Южного, Юго-Восточного и Восточного Казахстана. Она сотрудничала с видным археологом Х. А. Алпысбаевым по изучению палеолитических стоянок Южного Казахстана.

Еще будучи школьницей, Саида с удовольствием ходила к маме на работу, подолгу сидела в палинологической лаборатории, наблюдая за тем как лаборанты занимаются выделением пыльцы из геологических пород. Мама учила работать с микроскопом, рассказывала о возможности применения спорово-пыльцевого анализа в геологии, медицине, криминалистике, археологии. Раиса Биктемировна была очень увлеченным человеком и смогла увлечь дочь.

В 1987 году Саида Нигматова поступила в КазГУ им. С. М. Кирова на биологический факультет. Вопросов с выбором специализации не было, поэтому с 1990 года после второго курса она пришла в Институт геологических наук, где тогда была крупная палинологическая лаборатория, и под руководством 3. К. Пономаренко приступила к изучению палеогеновой пыльцы Торгая. Уже тогда было ясно, что детство, проведенное в лаборатории и полях, не прошло даром: Саида увлеклась споровопыльцевым анализом и проявляла явные способности. Дорога в геологию была предопределена, но грянул развал СССР. Институт геологических наук испытывал трудности, поэтому прием на работу молодого специалиста стал проблематичным.
По счастливому стечению обстоятельств, в это же время при Институте ботаники и фитоинтродукции АН РК начали формировать палеоботаническую лабораторию под руководством Петра Владимировича Шилина, который и пригласил выпускницу С. А. Нигматову поступить в аспирантуру. В 1992 году С. А. Нигматова поступила в аспирантуру Института ботаники и фитоинтродукции к П. В. Шилину и занялась изучением ископаемой флоры Торгая. Было интересно сравнить макро- и микрофлору. Отпечатки растений оказались интересным объектом изучения и позволяли значительно расширить представления о древней флоре Казахстана и изменению климата кайнозоя. С. А. Нигматовой была монографически изучена коллекция ископаемых растений местонахождения Ержилансай в Тургае. Эта коллекция собиралась долгие годы Валентиной Степановной Корниловой, Эльзой Васильевной Романовой, Раисой Биктемировной Байбулатовой и в ходе экспедиции 1995-1996 гг. самой Саидой Нигматовой.

В 1998 г. она защитила кандидатскую диссертацию по палеоботанике «Ископаемая флора Ержилансая (Торгайский прогиб)». Однако интерес к изучению ископаемой пыльцы не угасал: «Палинология, как первая любовь, со мной навсегда», - шутила Саида, когда у нее спрашивали: «Не забросила ли она палинологию?».

В 1999 году С. А. Нигматова с группой ботаников приняла участие в работе комплексной Казахскофранцузской экспедиции по изучению берелских курганов под руководством Зайноллы Самашевича Самашева. Это был переломный момент! За научной консультацией и помощью в 
лабораторной обработке образцов на палинологический анализ С. А. Нигматова обратилась в Институт геологических наук к известному геологу Болату Жагыфаровичу Аубекерову, возглавлявшему в то время лабораторию четвертичной геологии. В свою очередь Б. Ж. Аубекеров предложил восстановить работу палинологической группы в Институте, за эту работу, засучив рукава, и взялся молодой кандидат наук Саида Нигматова.

Палинологическое изучение материалов археологических памятников позволил получить интереснейший материал. Так, по берелским курганам были получены данные о сезоне захоронения, сделаны выводы о разных местах обитания лошадей из сопроводительного комплекса кургана № 11 и многие другие выводы.

Б. Ж. Аубекеров развивал новое для Казахстана направление - геоархеологические исследования. Он внедрял в работы археологов представления о необходимости изучения геоморфологии района, его геологической истории, настаивал на изучении климата времени существования археологических объектов. Саида Нигматова активно поддерживала развитие геоархеологического направления. Она выступала на семинарах и конференциях, популяризуя палинологические исследования для нужд археологии.

В ходе выполнение гранта INTAS «Процесс формирования кочевых племен в Семиречье в бронзовом и раннежелезном веках. Экология и археология» были собраны уникальные материалы по изменению климата и растительности в горных, предгорных и пустынных областях Семиречья/ Жетысу. Совместные работы с археологами Алексеем Евгеньевичем
Рогожинским, Александром Анатольевичем Горячевым, а также Ренато Сала (Renato Sala) и Жан-Марком Деомом (Jean-Marc Deom) позволили увязывать изменения растительности и климата с развитием и изменением типов хозяйства, формированием и угасанием культур на территории Юго-Восточного Казахстана.

В 2002 году С. А. Нигматова поступила на работу в Институт геологических наук им. К. И. Сатпаева (ИГН). Необходимость в ней как в специалисте-палинологе назрела в связи с расширением палинологических работ, проводимых в лаборатории мезозоя и кайнозоя. К тому времени от былой славы палинологической лаборатории почти ничего не осталось: финансирования не было, работа была приостановлена. Но назревал нефтяной бум и постепенно росла потребность в комплексных исследованиях керна. После прихода С. А. Нигматовой в ИГН была вновь сформирована палинологическая группа, сориентированная на выполнение хоздоговорных и фундаментальных исследований. С. А. Нигматовой была успешно выполнена организационная и кадровая работа, в результате которой были закуплены химические реактивы, химическая посуда, приборы, приняты новые сотрудники. Вся эта большая работа способствовала тому, что в настоящее время палинологическая группа ИГН им. К. И. Сатпаева является одной из лучших палинологических лабораторий в Казахстане, изучающей отложения от верхнего палеозоя до голоцена включительно.

Помимо производственных мероприятий, С. А. Нигматовой выполнялась большая научная работа и постоянно совершенствовался про- 


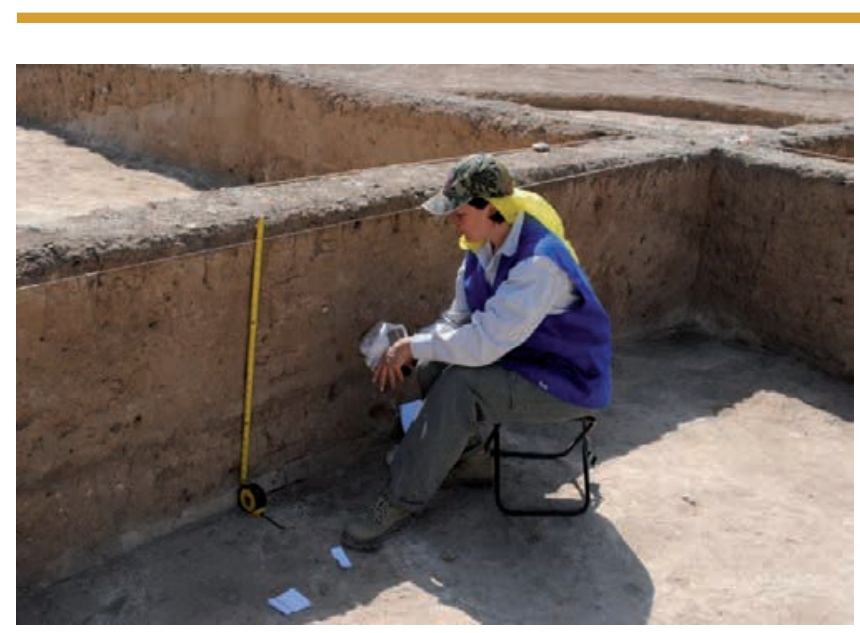

Рис. 2. С.А. Нигматова. Сауран, 2011

Fig. 2. Saida A. Nigmatova. Sauran, 2011

фессиональный уровень. Б. Ж. Аубекеров поставил задачу: поскольку финансирование весьма скудное, из каждой экспедиции надо привезти максимально большое количество информации - собирать поверхностные пробы, делать геоморфологические описания, описания растительности, отбирать образцы из пойменных отложений, наилков, собирать гербарий.

Она прошла стажировки в МГУ им. М. В. Ломоносова и университетах штата Луизиана и Техас (США). Стажировка в Москве в 2003 г. была предоставлена НАН РК как молодому перспективному специалисту.

В 2002-2008 годах было выполнено палинологическое изучение лессовых отложений Южного Казахстана, в том числе включающих археологические объекты Бутакты (по приглашению Александра Анатольевича Горячева), Майбулак (совместно с Жакеном Кожахметовичем Таймагамбетовым), Трамплин, Чарын/Шарын и др. Были показаны изменения климата в плювиальные эпохи, сопоставимые с оледенениями, и аридные - с межледниковьем.
Большая работа по изучению кернов донных отложений была проведена в ходе международных исследований озера Балхаш по международному проекту. Был изучен девятиметровый керн и получено шесть этапов увеличения обводненности озера и его обмеления.

Продолжается работа и на археологических объектах: изучены отложения археологическогопамятника Кердары (район Аральского моря, экспедиция под руководством Дмитрия Воякина), курганы Жетысу и Алтая, поселения эпохи бронзы и раннего железного

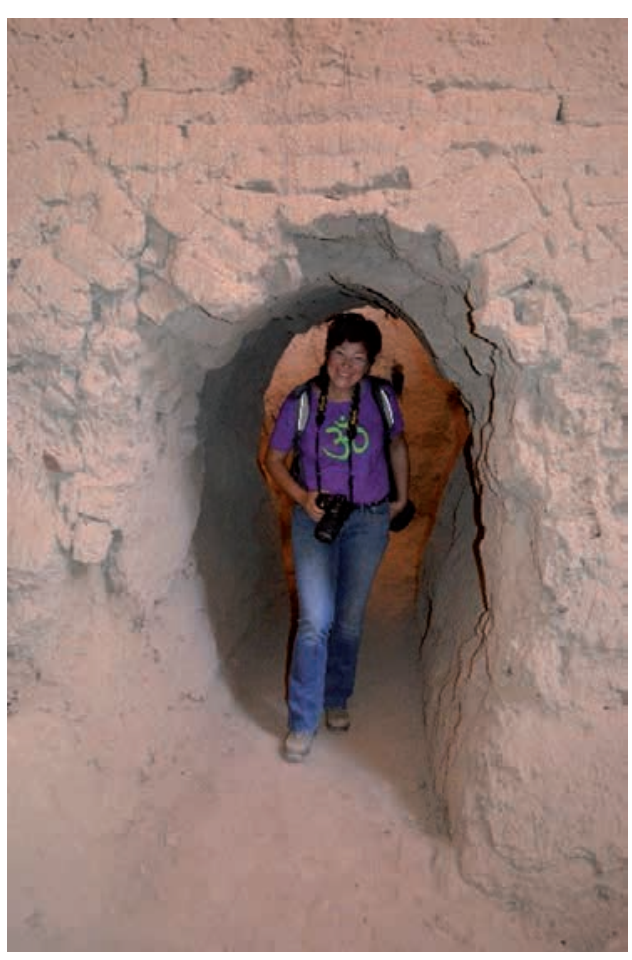

Рис. 3. С.А. Нигматова. Культобе, 2018 Fig. 3. Saida A. Nigmatova Kultobe, 2018 
века в горах Шу-Иле и Иле Алатау. Впервые проведено биозональное расчленение голоценовых отложений и проведена увязка с основными археологическими событиями.

В 2010 году С. А. Нигматовой защищена докторская диссертация на тему «Стратиграфия, палеогеография и климаты четвертичного периода аридных регионов Центральной Азии (по палинологическим данным)», куда вошли полученные данные.

В 2012 г., после безвременной кончины руководителя лаборатории мезозоя и кайнозоя учителя и друга Б. Ж. Аубекерова, Саида Нигматова возглавила лабораторию. Были продолжены работы по палинологическому изучению кернов нефтяных скважин, археологических объектов, геологических разрезов. В 2015 г. был подготовлен к печати коллективный труд сотрудников лаборатории «Атлас руководящих комплексов спор, пыльцы и фораминифер мезозойских нефтегазоносных отложений Торгайского осадочного бассейна» и «Методическое руководство по палинологическому изучению юрских отложений Южного Торгая и прилегающих территорий».

Начиная с 2012 г. и по настоящее время, С. А. Нигматова занимается изучением археологических памятников Южного Казахстана: Отpap, Сауран, Миртобе. Наиболее интересные результаты были получены при изучении памятника Миртобе, куда С. А. Нигматова была пригла- шена Ербулатом Акижановичем Смагуловым. Здесь установлена пыльца многих культурных растений, позволяющих реконструировать более благоприятные климатические условия, что способствовало развитию садов и огородов.

Помимо интереса к изучению пыльцы, Саида Араповна постепенно начинает заниматься изучением плодов и семян, отобранных на археологических памятниках. В комплексе с палинологическим анализом карпология позволяет значительно корректней изучать растения, используемые в древности как в пищевых, так и в медицинских целях. Сейчас формируется база данных по плодам и семенам из различных отложений Южного и Восточного Казахстана, а также эталонная коллекция плодов и семян.

С. А. Нигматова ведет работу с молодыми специалистами. В течение двух лет она вела палинологические семинары в КазНУ им. аль-Фараби, под ее руководством защищено две магистерские диссертации. Она ассоциированный профессор кафедры Геологии нефти и газа КазНИТУ им. К. И. Сатпаева. С. А. Нигматова пользуется заслуженным авторитетом и уважением коллег, она является чутким и отзывчивым товарищем.

Сегодня Нигматова Саида Араповна является связующей нитью между разными отраслями и специалистами, объединенными Наукой о Земле - геологами, палеонтологами, археологами.

\section{Авторефераты:}

\section{Список основных публикаций С. А. Нигматовой}

1 Ископаемая флора Ержилансая (Тургайский прогиб): автореф. дис. канд. биол. наук: 03.00.05. Алматы: Ин-т ботаники АН РК, 1998. 18 с. 
2 Стратиграфия, палеогеография и климаты четвертичного периода аридных регионов Центральной Азии (по палинологическим данным): автореф. дис. докт. геол.-мин. наук. Алматы: Институт геологических наук им. К.И. Сатпаева МОН РК, 2010. $27 \mathrm{c}$.

\section{Главы в книгах}

1. Геоморфологическое строение и природные ландшафты Казахстана // Ерофеева И.В. (отв. ред.). Историко-культурный атлас казахского народа. Алматы: "Print-S", 2011. С. 6-21 (в соавторстве с Аубекеровым Б.Ж.).

2. Геолого-географические и палинологические исследования на археологическом комплексе Бутакты-1 // Горячев А.А., Мотов Ю.А. Археологический комплекс Бутакты-1. Алматы: TOO “KazBookTrade”, 2018. С. 156-171 (в соавторстве с Аубекеровым Б.Ж., Кузнецовой Л.Л.).

\section{Статьи:}

1. К вопросу о формировании аридной зоны в Казахстане // Вестник КазНТУ. 2009. № 6. С. 14-17 (в соавторстве с Аубекеровым Б.Ж.).

2. Четвертичное оледенение гор Северного Тянь-Шаня // Доклады АН Республики Таджикистан. 2009. Т. 52. С. 959-962 (в соавторстве с Аубекеровым Б.Ж., Перевозовым С.В.).

3. Начальный этап формирования аридной зоны Центральной Азии // Труды Института геологии. Новая серия. 2009. Вып. 8. С. 131-139 (в соавторстве с Аубекеровым Б.Ж.).

4. Геоархеологическое изучение озера Балхаш как географического центра культур Казахстана // Роль номадов в формировании культурного наследия Казахстана: сб. м-лов Междунар. научн. конф. «Научные чтения памяти Н.Э. Масанова» (г. Алматы, 23-24 апреля 2009 г.). Алматы: Print-S, 2009. C. 37-45 (в соавторстве с Аубекеровым Б.Ж., Сала Р., Деомом Ж.-М., Ерофеевой И.В.).

5. Prehistorical and Historical Stages of development of Lake Balkhash // Reconseptualizing Cultural and Environmental Change in Central Asia. 2010. P. 49-76 (coauthors: Aubekerov B.Z., Sala R., Deom J.-M.).

6. О палинологических исследованиях лессовых отложений верхнего плейстоцена и голоцена предгорий Заилийского Алатау (Северный Тянь-Шань) // Вестник инженерной академии. 2010. № 1. С. 127-132.

7. Ecological Change in the Balkhash Region during the Last Two Millenia // Toward a Sustainable Society in Central Asia. 2012. P. 27-35(co-authors: Aubekerov B.Z., Voyakin D.).

8. Quaternary Evolution of the Human Habitats in the Ili-Balkhash Region from Paleolithic to Modern Times // Toward a Sustainable Society in Central Asia. 2012. P. 49-59 (co-authors: Aubekerov B.Z., Sala R., Deom J.-M.).

9. Lake Level Change and Environmental Evolution during the Last 8000 Years Mainly based on Balkhash Lake Cores in Kazakhstan, Central Eurasia // Toward a Sustainable Society in Central Asia. 2012. P. 35-49 (co-authors: Aubekerov B.Z., Sala R., Endo K., Haraguchi T.).

10. Палинологическая характеристика нижнеюрских отложений Южного Торгая // Известия НАН РК. Сер. геол. и техн. наук. 2013. № 4. С. 3-15 (в соавторстве с Дильмухамедовой Н.Р., Петровой Т.А., Ахматшаевой И.Т.).

11. Методическое руководство по палинологическому изучению юрских отложений Южного Торгая и прилегающих территорий. Алматы: б/и, 2015. 78 с. (в соавторстве с Дильмухамедовой Н.Р., Петровой Т.А.). 
12. Soviet, recent and planned studies of the behavior of the Balkhash lake // Известия НАН РК. Сер. геол. и техн. науки. 2016. № 2. С. 76-86 (co-authors: Sala R., Deom $J-M$. et all.).

13. Характеристика руководящих палинокомплексов юрских отложений Южно-Торгайского нефтегазоносного региона // Известия НАН РК. Сер. геол. и техн. наук. 2016. № 1 (415). С. 5-18 (в соавторстве с Дильмухамедовой Н.Р., Петровой Т.А., Авуловым 3.).

14. Горючие сланцы Южно-Торгайского нефтегазоносного бассейна» // Известия НАН РК. Сер. геол. и техн. наук. 2017. № 6. С. 5-17 (в соавторстве с Поповым В.А., Оздоевым С.М., Кузнецовой Л.Л., Касымханкызы А.).

15. Юрское озеро Каратау: современное состояние уникального местонахождения ископаемой флоры и фауны // Известия НАН РК. Сер. геол. и техн. науки. 2017. № 3. С. 10-23 (в соавторстве с Косенко А.А., Джумановым С., Усиповой А.Б., Шермахан Б.).

16. Археологическое и палинологическое изучение курганов могильника Каспан-6 в Жетысу // Бейсенов А.З. (отв. ред.). Археологическое наследие Центрального Казахстана: изучение и сохранение: сб. научн. ст., посвящ. 70-летию организации ЦКАЭ АН Казахстана. Алматы: НИЦИА «Бегазы-Тасмола», 2017. Т. 2. С. 135-143 (в соавторстве с Джумабековой Г.С., Базарбаевой Г.А.).

17. Юрское озеро Каратау: современное состояние уникального местонахождения ископаемой флоры и фауны // Известия НАН РК. Сер. геол. и техн. науки. 2017. № 3. С. 10-23 (в соавторстве с Косенко А.А., Джумановым С., Усиповой А.Б., Шермахан Б.).

18. Reevaluation of Late Pleistocene loess profiles at Remizovka (Kazakhstan) indicates the significance of topography in evaluating terrestrial paleoclimate records // Quaternary Research. 2018. 89. P. 674-690 (co-authors: Tobias Sprafke, K.E. Fitzsimmons, Christoph Grützner, Austin Elliot, Laurent Marquerand).

19. The new data on biostratigraphy of the basic geological section of the continental Cenozoic deposits of Aktau mountains (South-East Kazakhstan, Ili basin) (Новые данные по биостратиграфии опорного разреза континентальных кайнозойских отложений гор Актау (Юго-Восточный Казахстан, Илийская впадина) // Известия НАН РК. Cер. Геология и техн. науки. 2018. № 5. С. 150-162 (co-authors: Bayshashov B.U., Zhamangara A.K., Lucas S.G., Bayadilov K.O., Kasymkhankyzy A.).

\section{Сведения об авторе:}

Жамангара Айжан Кашаганкызы - кандидат биологических наук, заместитель директора по науке, «Астанинский ботанический сад» - Филиал РГП на ПХВ «Институт ботаники и фитоинтродукции» Комитета лесного хозяйства и животного мира Министерства экологии, геологии и природных ресурсов РК (Нур-Султан, Казахстан); kashagankizi@mail.ru

\section{ПАЛИНОЛОГТАР ӘУЛЕТІНІҢ САҚТАУШЫСЫ}

\section{А. К. Жаманғара}

Ғалым палеонтолог, палинолог, геолог, геоархеолог Нигматова Саида Арапқызының мерейтойын атап өтеді. С. А. Нигматова ғажайып палинологтар әулетінің жалғастырушысы болып табылады. С. А. Нигматова палеоботаника, биостратиграфия және геоархеология ғылымдарына ауыз толтырып айтарлықтай үлесін қосты. Мақалада С. А. Нигматованың аспирантурадан бастап Қазақстандағы Қ. И. Сәтбаев атындағы Геологиялық ғылымдар институтының бірден-бір палинология зертханасын басқарушы танымал ғалым болып қалыптасуына дейінгі ғылыми жолы қысқаша 
баяндалған. Сонымен қатар, мақалада С. А. Нигматованың археология ғылымына қосқан орасан зор үлесі туралы баяндалған. С. А. Нигматованың палинологиялық талдау негізінде алған тұжырымдары Қазақстан аумағындағы әртүрлі мәдени өсімдіктерінің қалыптасуының табиғи-климаттық жағдайының көрінісін өрістетуге мүмкіндік берді.

Түйін сөздер: Нигматова Саида Араповна, палинология, палеонтология, геоархеология

\section{PALYNOLOGISTS DYNASTY KEEPER}

\section{A. K. Zhamangara}

Saida A. Nigmatova, paleontologist, palynologist, geologist, geoarchaeologist, celebrates her anniversary. Nigmatova S. A. is a successor to the amazing family dynasty of palynologists. Nigmatova S .A. made a significant contribution to paleobotany, biostratigraphy and geoarchaeology. The article summarizes scientific path of S. A. Nigmatova - from a graduate student to a famous scientist, who heads the only unique palynology laboratory at the K. I. Satpayev Institute of Geological Sciences in Kazakhstan. The article especially notes the significant contribution of S. A. Nigmatova to archaeological science. Conclusions obtained by S. A. Nigmatova on the basis of a palynological analysis made it possible to expand ideas about the natural and climatic conditions for the formation of different cultures in Kazakhstan.

Keywords: Nigmatova Saida A., palynology, paleontology, geoarchaeology

\section{About the Author:}

Zhamangara Aizhan K. Candidate of biological sciences, deputy director for science, "Astana Botanical Garden" - Branch of RSE at the "Institute of Botany and Phytointroduction" at the Committee for Forestry and Wildlife of the Ministry of Ecology, Geology and Natural Resources of the Republic of Kazakhstan, Nur-Sultan, Kazakhstan; kkashagankizi@mail.ru 